\title{
Full contents
}

Acknowledgements viii

Introduction 1

1 The P5's duty to prevent genocide under the Genocide

$\begin{array}{ll}\text { Convention } & 13\end{array}$

1 Introduction 13

2 The Genocide Convention 14

3 The Bosnian Genocide case 14

4 The scope and breach of the P5's duty to prevent genocide under the Genocide Convention 49

5 Conclusion $\quad 70$

2 The P5's duty to prevent genocide under customary international law $\quad 72$

1 Introduction $\quad 72$

2 Customary international law in general 73

3 The test for custom in case law - uncontroverted opinio juris - and its application to the duty to prevent genocide $\quad 76$

4 Conclusion

3 The conflict between the P5's duty to prevent genocide and the P5's rights and duties under conventional and customary international law

1 Introduction

2 Conflict within the Security Council: The P5's duty to prevent genocide and the P5's rights under Articles 39, 41, 42, and 27(3) of the UN Charter

3 Conflict without the Security Council: The P5's duty to prevent genocide and the P5's duty not to use force under conventional and customary law

4 Conclusion

4 Resolving the conflict between the P5's duty to prevent genocide and the P5's rights and duties under conventional and customary law 
1 Introduction 166

2 Article 103 of the UN Charter 167

3 Jus Cogens norms 173

4 Erga Omnes obligations 202

5 Conclusion 206

Conclusion 207

1 Summary analysis 207

2 Parting thoughts 215

$\begin{array}{ll}\text { Bibliography } & 217\end{array}$

Index 241 